\title{
Phospholipid Synthesis in the Human Arterial Intima*
}

\author{
Aram V. Chobanian $†$ and William Hollander \\ (From the Robert Daweson Evans Memorial Department of Clinical Research, University Hos- \\ pital, and the Department of Medicine, Boston University School of Medicine, \\ Boston, Mass.)
}

The accumulation of lipids within the arterial intima represents an important feature in the development of the atherosclerotic lesion. Although much interest has been centered on the relationship between blood lipid levels and atherosclerosis, limited information is available in man concerning the intimal metabolism of lipids and its possible role in lipid accumulation within the vessel wall. Previous studies indicate, however, that the human intima is in fact a dynamic tissue involved in a number of metabolic processes (2), and preliminary observations suggest that the human intima can synthesize lipids, proteins, and lipoproteins $(3,4)$.

Interest in the arterial metabolism of phospholipids is derived in part from the apparent biological role of phospholipids in the transport of lipids (5) and from the observations that the total phospholipid content of the arterial wall increases with the severity of atherosclerosis $(6,7)$. All phospholipid groups appear to share in this increase, although the major rise of phospholipid in the atherosclerotic lesion occurs in the sphingomyelin fraction $(7,8)$. Studies in rabbits by McCandless and Zilversmit have demonstrated intimal phospholipid synthesis and have suggested that this local synthesis accounts for the major source of arterial phospholipid (9). Subsequent indirect studies in man have likewise suggested the presence of local intimal synthesis on the basis of higher phospholipid specific activities in the

* Submitted for publication November 4, 1965 ; accepted March 2, 1966.

Supported in part by grants HE-07299-03 and HE01536-11 from the U. S. Public Health Service and by the U. A. Whitaker Fund.

Presented in part at the Annual Meeting of the American Federation for Clinical Research, May 3, 1964, and published in abstract form (1).

+ Address requests for reprints to Dr. Aram V. Chobanian, University Hospital, 750 Harrison Ave., Boston, Mass. 02118. intima as compared with the plasma after infusions of inorganic ${ }^{32} \mathrm{P}(10)$. To approach the problem more directly, the present investigation has been undertaken to study the synthesis of phospholipids in isolated segments of human arterial intima and to characterize and compare the individual phospholipids formed in situ.

\section{Methods}

Human arterial tissue specimens were obtained either at postmortem examination within 4 hours of death or at the time of surgery for vascular disease or limb amputations. Segments of the descending portion of the thoracic aorta were used in all of the studies involving postmortem material (Patients 1, 2, 3, 8, and 10). The surgical specimens included aortic segments from areas surrounding atherosclerotic aneurysms of the thoracic and abdominal aorta and segments of femoral artery obtained from amputated limbs. The degree of atherosclerosis was graded by visual inspection as previously described (11). The adventitia and most of the media were carefully stripped away, and the remaining tissue, which was found by microscopic examination to be comprised of the entire intima and a small portion of adherent media, was divided into approximately $1-\times 1-\mathrm{cm}$ sections. The blood vessel segments thus prepared were suspended in $10 \mathrm{ml}$ of incubation solution ${ }^{1}$ containing inorganic ${ }^{32} \mathrm{P}$ ( $5.0 \mu \mathrm{c}$ per $\mathrm{ml}$, carrier free) and were incubated in an atmosphere of $95 \%$ oxygen and $5 \%$ carbon dioxide for 4 to 24 hours at $37^{\circ} \mathrm{C}$ in a Dubnoff shaker. In Patients 1,2, 5, and 6, tissue aliquots were also incubated in solution containing acetate- $1-{ }^{14} \mathrm{C}^{2}$ (1.0 $\mu \mathrm{c}$ per $\mathrm{ml}$, SA $53.0 \mathrm{mc}$ per mmole). In Subjects 1, 2, 7, and 10, intimal segments were incubated in a medium containing albumin $\left(50 \mathrm{mg}\right.$ per $\mathrm{ml}$ ) and palmitate $-{ }^{14} \mathrm{C}(0.5 \mu \mathrm{c}$ per $\mathrm{ml}$, SA $3 \mathrm{mc}$ per mmole).2, 3 All incubations were begun be-

1 Composition: $\mathrm{Na} 130 \mathrm{mEq}$ per $\mathrm{L}, \mathrm{K} 4.0 \mathrm{mEq}$ per $\mathrm{L}$, Ca $3.0 \mathrm{mEq}$ per $\mathrm{L}, \mathrm{Cl} 109 \mathrm{mEq}$ per $\mathrm{L}$, and lactate 28 $\mathrm{mEq}$ per L.

2 Obtained from the New England Nuclear Corp., Boston, Mass.

3 The radiopurity of the palmitate was determined by gas liquid chromatography after methylation with boron trifluoride. The analyses were carried out on a diethylene glycol succinate polyester column (20\% wt/wt) us- 
tween 3 and 6 hours after a patient's death or within 1 hour of surgical removal of tissue. Arterial tissue that could not be incubated within 6 hours of death was not utilized in these studies. Previous studies had demonstrated that when longer intervals (14 to 25 hours) were present between death and the beginning of incubation, the total phospholipid synthesis was negligible (less than $10 \%$ of the lowest value reported here). Cultures taken of selected samples of the incubation fluid at the end of incubation revealed no growth of bacteriological organisms.

After incubation, the tissues were washed five times, blotted, minced, and then homogenized in chloroformmethanol 2:1 (vol/vol). Aliquots of the minced tissue were dried to a constant weight, and all results were expressed in terms of the dry tissue weight. The lipids were extracted from the homogenate by the method of Folch, Lees, and Sloane Stanley (12) and were separated by silicic acid chromatography into fractions containing neutral lipids and individual phospholipid groups as described by Newman, Liu, and Zilversmit (13). Serial elutions were carried out using $50 \mathrm{ml}$ chloroform (vol/ vol), $50 \mathrm{ml} 20 \%$ methanol in chloroform, $150 \mathrm{ml} 40 \%$ methanol in chloroform, $50 \mathrm{ml} 60 \%$ methanol in chloroform, and $50 \mathrm{ml}$ methanol to yield, respectively, neutral lipids, noncholine-containing phospholipids, lecithins, sphingomyelins, and lysolecithins. The eluates from the column were collected in five major fractions according to the different solvents used. Duplicate aliquots of each fraction were analyzed for lipid phosphorus content by the method of Bartlett (14) and for lipid- ${ }^{32} \mathrm{P}$ or ${ }^{14} \mathrm{C}$ radioactivity in a liquid scintillation spectrometer after addition of $18 \mathrm{ml}$ scintillation solution (11). Because analyses of the column eluates revealed incomplete separation of the noncholine-containing phospholipids from lecithins and of lecithins from sphingomyelins, further separation of the phospholipids was carried out by thin layer chromatography. The latter technique could not be used alone, since the large amounts of lipid in the tissue extracts overloaded the capacity of the thin layer system. Duplicate aliquots of the column extracts were reduced to a smaller volume, transferred to pointed tubes, and then taken to dryness at room temperature under a stream of nitrogen. The residue was redissolved in $0.2 \mathrm{ml}$ of chloroform-methanol $2: 1$ (vol/vol), and the phospholipids in each duplicate fraction were separated by two dimensional thin layer chromatography according to the method of Skidmore and Entenman (15). The plates were exposed to iodine vapors, and the individual phospholipid spots were circled and identified by comparison with known phospholipid standards. ${ }^{4}$ Excellent separation of varying mixtures of standards of phosphatidyl serine, phosphatidyl ethanolamine, lecithin, sphingomyelin, and phosphatidyl inositol was achieved. The iodine

ing a modular chromatograph with an ionization detector. The column effluents were collected at the gas liquid chromatography outflow portal under liquid nitrogen and analyzed for ${ }^{14} \mathrm{C}$ radioactivity. The radiopurity as determined by this method varied between 97 and $99 \%$.

4 Obtained from Sigma Chemical Co., St. Louis, Mo. was allowed to evaporate, and the phospholipid spots and surrounding $0.5 \mathrm{~cm}$ of silica gel were scraped individually from the plate to weighing papers. When a given phospholipid group was present on more than one plate as usually occurred with the lecithins and sphingomyelins, the comparable spots were combined. The silica gel fractions containing phosphatidyl serine and phosphatidyl ethanolamine were combined and analyzed together for total radioactivity and lipid phosphorus content. The silica gel samples from one of the duplicate sets were suspended in toluene scintillation solution containing $4 \mathrm{~g}$ per $100 \mathrm{ml}$ of thixotropic gel 5 and were counted directly in the liquid scintillation spectrometer. The silica gel fractions from the remaining set were transferred to conical tubes, and the phospholipids were extracted by the method of Abramson and Blecher (16). Lipid phosphorus content and radioactivity of the extracted material were measured as previously noted. The lipid phosphorus values were multiplied by 25 to convert to phospholipid. To detect possible contamination of the sphingomyelin by other phosphatides, we treated aliquots of the extract from the sphingomyelin-containing silica gel with $\mathrm{KOH}$ and separated the fractions according to the method of Schmidt, Benotti, Hershman, and Thannhauser (17). The total phosphorus content and radioactivity of the extracts were confined to the alkali-resistant sphingomyelin-containing fraction. Analyses of the silica gel in the areas intervening between the individual phospholipid spots revealed only trace amounts of phospholipid content or radioactivity. No significant radioactivity was present in the areas of the chromatogram where phosphatidyl inositol would have been expected to migrate. Small amounts of phospholipid ranging between 0.5 and $3.5 \%$ of the total applied to a plate remained at the origin. The recovery of phospholipid from the silicic acid column averaged $98 \%$ (range 94 to 101\%). The recovery from the silica gel of lecithin averaged $86 \%$ (range 80 to $89 \%$ ), of sphingomyelin $84 \%$ (range 80 to $86 \%$ ), and of phosphatidyl serine and phosphatidyl ethanolamine $69 \%$ (range 64 to $71 \%$ ). The results were corrected to allow for the decreased recovery of the phospholipids from the silica gel. All samples were counted to a statistical accuracy of $4 \%$ (18). The silica gel and thixotropic gel mixtures did not produce significant quenching of either lipid- ${ }^{14} \mathrm{C}$ or ${ }^{22} \mathrm{P}$ radioactivity.

In Patients 1 and 10, grossly normal portions of aorta were dissected away from atherosclerotic sites, and the tissues thus divided were analyzed separately.

In Patient 1, the cephalin- and lecithin-containing fractions of tissue incubated with acetate $-{ }^{14} \mathrm{C}$ were saponified according to the method of Albrink (19), and the fatty acid- and glycerol-containing moieties were counted separately for ${ }^{14} \mathrm{C}$ radioactivity.

Control samples of intima, heat killed by immersion in boiling water for 2 minutes, were also incubated with the radioactive phospholipid precursors and analyzed for phospholipid radioactivity. None of the heat-killed specimens contained significant lipid- ${ }^{32} \mathrm{P}$ or ${ }^{14} \mathrm{C}$ radioactivity.

\footnotetext{
${ }^{5}$ Cabot Corp., Boston, Mass.
} 
TABLE I

Incorporation of inorganic ${ }^{32} P$ into intimal phospholipids

\begin{tabular}{|c|c|c|c|c|c|c|c|c|c|c|c|}
\hline \multirow[b]{2}{*}{ Patient } & \multirow{2}{*}{$\begin{array}{l}\text { Age } \\
\text { and } \\
\text { sex }\end{array}$} & \multirow[b]{2}{*}{ Tissue } & \multirow{2}{*}{$\begin{array}{c}\text { Degree } \\
\text { athero- } \\
\text { sclerosis } \\
(0-4+)\end{array}$} & \multicolumn{4}{|c|}{ Phospholipid content } & \multicolumn{4}{|c|}{${ }^{82} \mathrm{P}$ incorporation into phospholipid } \\
\hline & & & & Total & $\begin{array}{l}\text { Ceph- } \\
\text { alin }\end{array}$ & $\begin{array}{l}\text { Leci- } \\
\text { thin }\end{array}$ & $\begin{array}{l}\text { Sphingo- } \\
\text { myelin }\end{array}$ & Total & $\begin{array}{l}\text { Ceph- } \\
\text { alin }\end{array}$ & $\begin{array}{l}\text { Leci- } \\
\text { thin }\end{array}$ & $\begin{array}{c}\text { Sphingo- } \\
\text { myelin }\end{array}$ \\
\hline 1 & $72 \mathrm{M}$ & $\begin{array}{c}\text { Thoracic } \\
\text { aorta }\end{array}$ & $0-1+$ & 9.0 & $\mathrm{mg}_{1.5} \mathrm{~g}$ & $y w t$ & 3.3 & 10.8 & $\begin{array}{l}m_{\mu c} / \\
3.9\end{array}$ & 6.9 & 0 \\
\hline 2 & $3 \mathbf{M}$ & $\begin{array}{c}\text { Thoracic } \\
\text { aorta }\end{array}$ & $\mathbf{0}$ & 11.0 & 2.5 & 4.3 & 2.5 & 49.2 & 24.1 & 25.1 & 0 \\
\hline 3 & $39 \mathrm{M}$ & $\begin{array}{c}\text { Thoracic } \\
\text { aorta }\end{array}$ & $0-1+$ & 23.0 & 4.0 & 11.3 & 5.3 & 18.4 & 8.5 & 9.9 & $\mathbf{0}$ \\
\hline 4 & $72 \mathrm{M}$ & $\begin{array}{c}\text { Abdominal } \\
\text { aneurysm }\end{array}$ & $4+$ & 32.3 & 2.3 & 8.8 & 17.2 & 86.1 & 23.6 & 57.6 & 4.90 \\
\hline 5 & $70 \mathrm{~F}$ & $\begin{array}{l}\text { Thoracic } \\
\text { aneurysm }\end{array}$ & $4+$ & 34.3 & 9.8 & 11.7 & 12.0 & 14.5 & 4.7 & 9.3 & 0.46 \\
\hline 6 & $48 \mathrm{~F}$ & $\begin{array}{r}\text { Femoral } \\
\text { artery }\end{array}$ & $3-4+$ & 51.0 & 7.3 & 14.5 & 24.5 & 5.8 & 2.0 & 3.7 & 0.10 \\
\hline 7 & $66 \mathrm{~F}$ & $\begin{array}{r}\text { Femoral } \\
\text { artery }\end{array}$ & $4+$ & 33.0 & 6.0 & 10.5 & 13.0 & 59.8 & 6.7 & 52.7 & 0.38 \\
\hline 8 & $68 \mathrm{~F}$ & $\begin{array}{c}\text { Thoracic } \\
\text { aorta }\end{array}$ & $4+$ & 50.3 & 7.5 & 18.0 & 19.5 & 14.4 & 11.5 & 2.8 & 0.08 \\
\hline 9 & $62 \mathrm{M}$ & $\begin{array}{r}\text { Femoral } \\
\text { artery }\end{array}$ & $4+$ & 112.8 & 22.5 & 38.8 & 43.8 & 189.6 & 25.3 & 162.0 & 2.30 \\
\hline 10 & $57 \mathrm{M}$ & $\begin{array}{c}\text { Thoracic } \\
\text { aorta }\end{array}$ & $3-4+$ & 45.8 & 5.0 & 11.1 & 27.0 & 10.2 & 2.8 & 7.1 & 0.25 \\
\hline
\end{tabular}

\section{Results}

Table I summarizes the results of the incubation studies when inorganic ${ }^{32} \mathrm{P}$ was used as the labeled phospholipid precursor.

Intimal phospholipid content. The phospholipid content of the intima averaged $40.3 \mathrm{mg}$ per $\mathrm{g}$ intima (range from 9.0 to 112.8). All atherosclerotic segments contained greater amounts of phospholipid (mean 51.4, SE $\pm 10.9 \mathrm{mg}$ per $\mathrm{g}$ ) than the normal tissue (mean $14.3, \mathrm{SE} \pm 5.4 \mathrm{mg}$ per $g$ ). Lecithin was the major phospholipid of normal intima, averaging $43 \%$ of total intimal phospholipids as compared with respective values of $27 \%$ and $19 \%$ for the sphingomyelins and cephalins. In atherosclerotic tissue, sphingomyelin was the predominant phospholipid fraction, representing $45 \%$ of total phospholipid, whereas the lecithins comprised $31 \%$ and the cephalins $16 \%$ of the total. Eighty-four to $98 \%$ of the total phospholipids present were in the lecithin, cephalin, and sphingomyelin fractions. No attempt was made to quantitate the other intimal phospholipids, since none of these showed significant lipid- ${ }^{32} \mathrm{P}$ radioactivity after incubation.

Incorporation of ${ }^{32} \mathrm{P}$. The rate of incorporation of inorganic ${ }^{32} \mathrm{P}$ into phospholipids averaged $26.1 \mathrm{~m} \mu \mathrm{c}$ per $\mathrm{g}$ per hour ( $\mathrm{SE} \pm 11.7$ ) in normal intima (Patients 1 to 3 ) and $54.3 \mathrm{~m} \mu \mathrm{c}$ per $\mathrm{g}$ per hour $(\mathrm{SE} \pm 25.3)$ in the atherosclerotic segments (Patients 4 to 10). Two to four time points were used to calculate the incorporation rates. The major incorporation of ${ }^{32} \mathrm{P}$ into phospholipids was in the lecithins and cephalins. The lecithin fraction contained the greatest ${ }^{32} \mathrm{P}$ radioactivity when

TABLE II

Incorporation of inorganic ${ }^{32} P$ into adjacent normal and atherosclerotic areas of thoracic aorta

\begin{tabular}{|c|c|c|c|c|c|c|c|c|c|}
\hline \multirow[b]{2}{*}{ Patient } & \multirow{2}{*}{$\begin{array}{c}\text { Degree } \\
\text { athero- } \\
\text { sclerosis } \\
(0-4+)\end{array}$} & \multicolumn{4}{|c|}{ Phospholipid content } & \multicolumn{4}{|c|}{${ }^{22} \mathrm{P}$ incorporation into phospholipid } \\
\hline & & Total & Cephalin & Lecithin & $\underset{\text { myelin }}{\text { Sphingo- }}$ & Total & Cephalin & $\begin{array}{l}\text { Leci- } \\
\text { thin }\end{array}$ & $\begin{array}{c}\text { Sphingo- } \\
\text { myelin }\end{array}$ \\
\hline & & \multicolumn{4}{|c|}{$m g / g d r y w t$} & \multicolumn{4}{|c|}{$m \mu c / g / h o u r$} \\
\hline 1 & $\begin{array}{r}0-1+ \\
4+\end{array}$ & $\begin{array}{r}9.0 \\
30.3\end{array}$ & $\begin{array}{l}1.5 \\
2.8\end{array}$ & $\begin{array}{l}3.8 \\
9.3\end{array}$ & $\begin{array}{r}3.3 \\
14.5\end{array}$ & $\begin{array}{l}10.8 \\
13.1\end{array}$ & $\begin{array}{l}3.9 \\
3.0\end{array}$ & $\begin{array}{l}6.9 \\
9.6\end{array}$ & $\begin{array}{l}0 \\
0.51\end{array}$ \\
\hline 10 & $\begin{array}{l}0-1+ \\
3-4+\end{array}$ & $\begin{array}{l}17.5 \\
45.8\end{array}$ & $\begin{array}{l}2.4 \\
5.0\end{array}$ & $\begin{array}{r}6.9 \\
11.1\end{array}$ & $\begin{array}{r}6.4 \\
27.0\end{array}$ & $\begin{array}{l}11.0 \\
10.2\end{array}$ & $\begin{array}{l}3.2 \\
2.8\end{array}$ & $\begin{array}{l}7.8 \\
7.1\end{array}$ & $\begin{array}{l}0 \\
0.25\end{array}$ \\
\hline
\end{tabular}




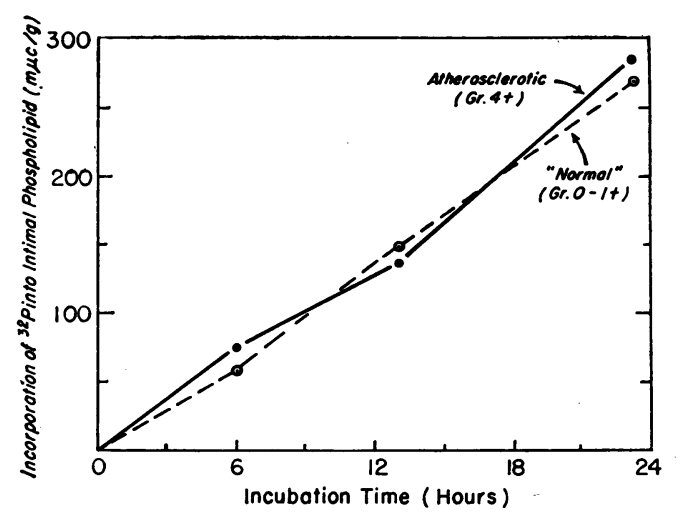

Fig. 1. InCORPORATION OF INORgaNiC ${ }^{22} \mathrm{P}$ into INTIMAL PHOSPHOLIPIDS IN NORMAL AND ATHEROSCLEROTIC AORTIC INTIMA.

compared according to tissue weight in nine of ten tissue studies. The phospholipid- ${ }^{32} \mathrm{P}$ specific activity was highest in the cephalin fraction in all normal tissues and in three of seven atherosclerotic segments. Significant incorporation of ${ }^{32} \mathrm{P}$ into sphingomyelin was evident in only atherosclerotic intima. In these atherosclerotic segments, the labeled sphingomyelin represented 0.5 to $5.7 \%$ of the total lipid- ${ }^{32} \mathrm{P}$ radioactivity, and the sphingomyelin specific activity was 1.4 to $10.4 \%$ of that of the total phospholipids in the intima.

In Patients 1 and 10, in whom adjacent normal and atherosclerotic tissues were available for analysis (Table II), the total phospholipid radioactivity in the relatively normal areas (10.8 and $11.0 \mathrm{~m} \mu \mathrm{c}$ per $\mathrm{g}$ per hour) was similar to that observed in the severely atherosclerotic segments (13.1 and $10.2 \mathrm{~m} \mu \mathrm{c}$ per $\mathrm{g}$ per hour). These results in Patient 1 are illustrated in Figure 1.
The incorporation of ${ }^{32} \mathrm{P}$ into sphingomyelin was measurable in the atherosclerotic segments but not in the adjacent relatively normal intima.

Incorporation of acetate $-{ }^{14} C$. Table III summarizes the results when acetate- ${ }^{14} \mathrm{C}$ was used as the phospholipid precursor. The rates of incorporation of acetate into phospholipid ranged from 1.88 to $5.02 \mathrm{~m} \mu \mathrm{c}{ }^{14} \mathrm{C}$ per $\mathrm{g}$ per hour. The major phospholipid- ${ }^{14} \mathrm{C}$ radioactivity was associated with the cephalin and lecithin fractions. A small amount of labeled sphingomyelin $(0.95 \%$ of the total phospholipid radioactivity) was present in one of the two normal vessels. In the two atherosclerotic tissues, sphingomyelin radioactivity represented 4.5 and $8.4 \%$ of the total phospholipid radioactivity. In Patient 1, after alkaline hydrolysis of the intimal phospholipid isolated by column chromatography, $76 \%$ of the ${ }^{14} \mathrm{C}$ radioactivity was present in the fatty acid and the remainder in the glycerol portion of the phospholipid molecule.

Incorporation of palmitate ${ }^{-14} \mathrm{C}$. The results of the incubation studies with palmitate- ${ }^{14} \mathrm{C}$ are summarized in Table IV. Significant incorporation of labeled palmitate into intimal phospholipids was observed in all tissues studied. The major incorporation of palmitate into phospholipid was present in the cephalins and lecithins with the former accounting for the major ${ }^{14} \mathrm{C}$ radioactivity in three of four instances. No significant sphingomyelin synthesis was demonstrable in either of the normal specimens. In the atherosclerotic intima, 2.9 and $8.4 \%$ of the total palmitate incorporated into phospholipid was present in the sphingomyelin fraction.

TABLE III

Incorporation of acetate- ${ }^{14} \mathrm{C}$ into intimal phospholipids

\begin{tabular}{|c|c|c|c|c|c|c|}
\hline \multirow[b]{2}{*}{ Patient } & \multirow[b]{2}{*}{ Tissue } & \multirow{2}{*}{$\begin{array}{l}\text { Degree } \\
\text { athero- } \\
\text { sclerosis } \\
(0-4+)\end{array}$} & \multicolumn{4}{|c|}{ Acetate- ${ }^{14} \mathrm{C}$ incorporation into phospholipid } \\
\hline & & & Total & Cephalin & Lecithin & $\begin{array}{c}\text { Sphingo- } \\
\text { myelin }\end{array}$ \\
\hline & & & \multicolumn{4}{|c|}{$m \mu c^{14} C / g /$ hour } \\
\hline 1 & $\begin{array}{c}\text { Thoracic } \\
\text { aorta }\end{array}$ & 0 & 2.11 & 1.48 & 0.61 & 0.02 \\
\hline 2 & $\begin{array}{c}\text { Thoracic } \\
\text { aorta }\end{array}$ & 0 & 1.88 & 1.27 & 0.61 & 0 \\
\hline 5 & $\begin{array}{l}\text { Thoracic } \\
\text { aneurysm }\end{array}$ & $4+$ & 5.02 & 1.40 & 3.20 & 0.42 \\
\hline 6 & $\begin{array}{r}\text { Femoral } \\
\text { artery }\end{array}$ & $3-4+$ & 2.68 & 0.97 & 1.59 & 0.12 \\
\hline
\end{tabular}


TABLE IV

Incorporation of palmitate ${ }^{-14} \mathrm{C}$ into intimal phospholipids

\begin{tabular}{ccccccc}
\hline \hline & & \multirow{2}{*}{$\begin{array}{c}\text { Degree } \\
\text { athero- } \\
\text { sclersis } \\
(0-4+)\end{array}$} & & \multicolumn{3}{c}{ Palmitate-14C incorporation into phospholipid } \\
\cline { 5 - 7 } Patient & Tissue & Total & Cephalin & Lecithin & $\begin{array}{c}\text { Sphingo- } \\
\text { myelin }\end{array}$ \\
\hline 1 & $\begin{array}{c}\text { Thoracic } \\
\text { aorta }\end{array}$ & $0-1+$ & 32.51 & 24.50 & 8.01 & 0 \\
2 & $\begin{array}{c}\text { Thoracic } \\
\text { aorta }\end{array}$ & 0 & 2.81 & 1.10 & 1.71 & 0 \\
7 & $\begin{array}{c}\text { Femoral } \\
\text { artery }\end{array}$ & $4+$ & 1.71 & 1.46 & 0.20 & 0.05 \\
10 & $\begin{array}{c}\text { Thoracic } \\
\text { aorta }\end{array}$ & $4+$ & 1.19 & 0.84 & 0.25 & 0.10 \\
\hline
\end{tabular}

\section{Discussion}

These studies suggest that the human arterial intima has the capacity to synthesize phospholipid. Phospholipid formation did not seem limited to any single portion of the phospholipid molecule. Synthesis of the glycerol and fatty acid moieties was suggested by the incorporation studies with acetate, formation of the phosphoric acid complex was indicated by the utilization of inorganic ${ }^{32} \mathrm{P}$, and incorporation of long chain fatty acid was apparent from the observations with labeled palmitate. The major phospholipids that appeared to be formed in both normal and atherosclerotic intima were the lecithins and cephalins. Most atherosclerotic intima incubated with either ${ }^{32} \mathrm{P}$, acetate, or palmitate synthesized more lecithins than cephalins. The results were more variable in normal intima, where cephalin synthesis predominated with acetate as a precursor, but no definite pattern was present when either ${ }^{32} \mathrm{P}$ or palmitate was used. Because of the limited number of patients studied, it is unclear whether the qualitative differences in phospholipid production observed with the different isotopic precursors in the normal and atherosclerotic tissues are indicative of actual differences in the rates of turnover of various portions of the phospholipid molecule.

The apparent rate of phospholipid synthesis in atherosclerotic tissue, when related to tissue weight, was similar to or more rapid than that observed in normal intima (depending upon whether the comparisons were made between adjacent normal and atherosclerotic areas of the same vessel or between different vessels). Since total intimal weight increases with atherosclerosis, the results suggest that total intimal phospholipid synthesis is greater in atherosclerotic than in normal tissue. The present findings are in agreement with those previously reported in rabbits by McCandless and Zilversmit (9).

Sphingomyelin synthesis appeared to be greater in atherosclerotic than in normal intima. All atherosclerotic tissue showed some incorporation of labeled precursor into sphingomyelin, whereas none of the normal tissues incubated with either ${ }^{32} \mathrm{P}$ or palmitate and only one incubated with acetate contained measurable quantities of labeled sphingomyelin after incubations lasting as long as 24 hours. A similar increased capacity for sphingomyelin synthesis in atherosclerotic tissue has previously been demonstrated in rabbits (9). The importance of these findings in relationship to the accumulation of sphingomyelin in atherosclerotic tissue is unclear. Indirect evidence does suggest that the plaque sphingomyelin may originate at least in part from local synthesis. Although a minor phospholipid constituent of the plasma, representing from 10 to $25 \%$ of the total plasma phospholipid $(20,21)$, sphingomyelin is the major phospholipid of the atherosclerotic lesion $(7,8)$ and accumulates predominantly at the base of the atherosclerotic plaque rather than the superficial areas of intima in closer proximity to the circulating blood (22). However, even in atherosclerotic lesions, the apparent rate of sphingomyelin formation was relatively slow compared to the rate of total phospholipid synthesis, suggesting that other factors might also contribute to intimal sphingomyelin accumulation. Relatively low synthesis rates for sphingomyelin have also been de- 
scribed in other human tissues by Crocker and Mays (23).

The effects of sphingomyelin accumulation within the intima are unclear. Published information is not as yet available concerning the tendency to develop atherosclerosis in patients with Niemann-Pick disease who have sphingomyelin accumulation within the body tissues. The physicochemical properties of sphingomyelin may differ somewhat from other phospholipids (24), but the biological implications of these differences are unknown.

These experiments have been concerned only with samples of arterial intima that were either severely atherosclerotic or relatively normal by gross appearance. Large amounts of tissue were needed for the analyses, and sufficient quantities of tissue from areas with intermediate degrees of atherosclerosis were not available for comparison. The present results, therefore, do not provide information concerning the possible sequence of changes in phospholipid synthesis that might occur in the development of the atherosclerotic lesion.

\section{Summary}

Phospholipid synthesis in the arterial wall has been studied in isolated human blood vessels that have been incubated with inorganic ${ }^{32} \mathrm{P}$, acetate${ }^{14} \mathrm{C}$, and palmitate $-{ }^{14} \mathrm{C}$. The results indicate that intimal phospholipid synthesis does occur and that the major phospholipids synthesized are the lecithins and cephalins. Sphingomyelin synthesis appears increased in atherosclerotic as compared with normal intima and may contribute to the observed accumulation of sphingomyelin in atherosclerotic plaques.

\section{Acknowledgments}

The authors express their thanks to Miss Suzanne Fortin for her expert technical assistance and to Dr. Robert W. Wilkins for review of the manuscript.

\section{References}

1. Chobanian, A. V., and W. Hollander. Phospholipid synthesis in human blood vessels (abstract). Clin. Res. 1964, 12, 178.

2. Kirk, J. E. Intermediary metabolism of human arterial tissue and its changes with age and atherosclerosis in Atherosclerosis and Its Origin, $M$.
Sandler and G. H. Bourne, Eds. New York, Academic Press, 1963, pp. 67-117.

3. Chobanian, A. V., and W. Hollander. Studies on fatty acid metabolism in human blood vessels (abstract). Clin. Res. 1963, 11, 216.

4. Chobanian, A. V., S. R. Cooperband, and W. Hollander. Studies of protein and lipoprotein synthesis in human and canine blood vessels (abstract). J. clin. Invest. 1965, 44, 1035.

5. Dixon, K. C. Fatty deposition: a disorder of the cell. Quart. J. exp. Physiol. 1958, 43, 139.

6. Buck, R. C., and R. J. Rossiter. Lipids of normal and atherosclerotic aortas. A chemical study. Arch. Path. 1951, 51, 224.

7. Böttcher, C. J. F., and C. M. Van Gent. Changes in the composition of phospholipids and of phospholipid fatty acids associated with atherosclerosis in the human aortic wall. J. Atheroscler. Res. $1961,1,36$.

8. Weinhouse, S., and E. F. Hirsch. Chemistry of atherosclerosis. I. Lipid and calcium content of the intima and of the media of the aorta with and without atherosclerosis. Arch. Path. 1940, 29, 31.

9. McCandless, E. L., and D. B. Zilversmit. The effect of cholesterol on the turnover of lecithin, cephalin, and sphingomyelin in the rabbit. Arch. Biochem. 1956, 62, 402.

10. Zilversmit, D. B., E. L. McCandless, P. H. Jordan, Jr., W. S. Henly, and R. F. Ackerman. The synthesis of phospholipids in human atheromatous lesions. Circulation 1961, 23, 370.

11. Chobanian, A. V., and W. Hollander. Body cholesterol metabolism in man. I. The equilibration of serum and tissue cholesterol. J. clin. Invest. 1962, 41, 1732.

12. Folch, J., M. Lees, and G. H. Sloane Stanley. A simple method for the isolation and purification of total lipides from animal tissues. J. biol. Chem. 1957, 226, 497.

13. Newman, H. A. I., C.-T. Liu, and D. B. Zilversmit. Evidence for the physiological occurrence of lysolecithin in rat plasma. J. Lipid Res. 1961, 2, 403.

14. Bartlett, G. R. Phosphorus assay in column chromatography. J. biol. Chem. 1959, 234, 466.

15. Skidmore, W. D., and C. Entenman. Two-dimensional thin-layer chromatography of rat liver phosphatides. J. Lipid Res. 1962, 3, 471.

16. Abramson, D., and M. Blecher. Quantitative twodimensional thin-layer chromatography of naturally occurring phospholipids. J. Lipid Res. 1964, 5, 628.

17. Schmidt, G., J. Benotti, B. Hershman, and S. J. Thannhauser. A micromethod for the quantitative partition of phospholipide mixtures into monoaminophosphatides and sphingomyelin. J. biol. Chem. 1946, 166, 505.

18. Loevinger, R., and M. Berman. Efficiency criteria in radioactive counting. Nucleonics 1951, 9 (no. 1), 26. 
19. Albrink, M. J. The microtitration of total fatty acids of serum, with notes on the estimation of triglycerides. J. Lipid Res. 1959, 1, 53.

20. Nelson, G. J., and N. K. Freeman. The phospholipid and phospholipid fatty acid composition of human serum lipoprotein fractions. J. biol. Chem. 1960, 235, 578.

21. Crocker, A. C., and S. Farber. Niemann-Pick disease: a review of eighteen patients. Medicine (Baltimore) 1958, 37, 1.
22. Adams, C. W. M., and O. B. Bayliss. Histochemical observations on the localisation and origin of sphingomyelin, cerebroside and cholesterol in the normal and atherosclerotic human artery. J. Path. Bact. 1963, 85, 113.

23. Crocker, A. C., and V. B. Mays. Sphingomyelin synthesis in Niemann-Pick disease. Amer. J. clin. Nutr. 1961, 9, 63.

24. Dervichian, D. G. The physical chemistry of phospholipids. Progr. Biophys. molec. Biol. 1964, 14, 263. 